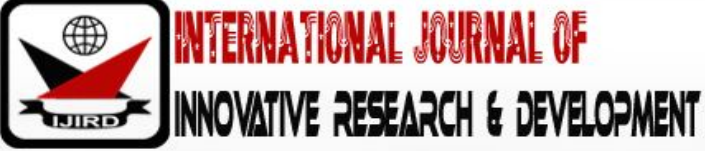

ISSN 2278 - 0211 (Online)

\section{Effects of School Building Conditions and School Location on Students' Academic Achievement in Colleges: A Study of Senior Secondary School Students in Adamawa State, Nigeria}

\author{
Dr. Nwachukwu A. Nwankwor \\ Lecturer, Department of Technology Education, \\ Midibbo Adama (Federal) University of Technology, Yola, Nigeria
}

\begin{abstract}
:
In the midst of several researches on the relationship between school (facilities) building conditions and student's academic achievement/ behaviour in many parts of the world, this study has built on some of these studies to examine the current effects school building conditions and school locations on academic achievement of secondary school students in Adamawa State as a contribution to the state governments' effort to revive the quality of education in the state. A total of 54 secondary schools, with 108 school administrators, were statistically selected from the 21 local government areas for the study. Four research questions and five null hypotheses guided this study. The students' scaled scores from their 2012/ 2013 and 2013/2014 NECO examinations were used as a standard measure of the students' academic achievement. The Mean and Percentages statistics were adopted in answering the research questions, while the t-test was employed in the testing of the hypotheses. The outcome of this study shows that: i. there are significant differences in secondary schools' building conditions within and across the educational zones; ii) the condition of school buildings have effect on students' academic achievement in favour of students schooling under standard buildings; iii) the effect of school building conditions are further stressed by the location of the schools, vis-avis, urban, semi-urban and rural locations. There is need therefore for an aggressive renovation of dilapidated school building while standard buildings need to be constructed, especially among the rural dwellings.
\end{abstract}

Keywords: School building conditions, school locations and secondary school students' academic achievement

\section{Introduction}

A school is a social system where students interact with their physical (facilities, spaces, lighting, thermal atmosphere, ventilation, ambience, air pollution) and psychological environments (other students and teachers) in the learning process (Cheng, 1994). The exchange between the students' personal characteristics and the school environment affect their learning attitude and behavior. On the other hand, building conditions are believed to have influence on the attitudes not only of the students in attendance, but on the parents and the school as well. The condition of a school facility can, and often does, send a clear message to students.

In Nigeria studies have been conducted in areas of school environment/ facilities and students school performance including those of Torupere, K., (2016), Daramola, D. S., Olutola, A. T. and Ogunjimi, M. O.(2017). Earlier on Lemasters, (1997) and Bailey, (2009), had also reviewed several other researches on the relationship between school facilities (building) conditions and students-teachers health and achievement. In that of Weinstein (1979) and McGuffey (1982) they concentrated on general area of school facilities and, as part of that body of research, looked at a limited number of studies that addressed the relationship between school building conditions and student achievement. These research reviews showed a lot of clear evidence that supports the commonly held assumption that there is a measurable relationship between the condition of a school building and the health and productivity of students and teachers. Nevertheless, some people still have some doubts as to the existence of any clear influence that the condition of a school buildings may have upon the students'/ teachers' health and performance. In some cases, policy makers, especially in Nigeria, still believe that because they attended school under the trees and still arrive they are, the condition of our school environment are secondary to such thinkers.

In Nigeria the national policy on education provides for a partnership funding between the states and the federal government in order to provide adequate facilities for the primary and secondary school systems. The states often faced with difficult financial decisions when it comes to the construction of new facilities and the maintenance of existing ones due to scarce resources. This notwithstanding, there is a growing national attention in Nigeria for closing the educational achievement gaps between students from different regions/ locations of the country.

This study was therefore set out to investigate the reality or imaginary differences in the achievement of secondary school students as a result of differences in their school building conditions and the moderation effects of their 
school locations. Specifically, the purpose of this study was to examine the influence of school building conditions on the academic achievement of secondary school students in Adamawa State, Nigeria. In the process of this investigation the study further examined whether differences in the schools' locations (urban, semi-urban and rural) add to the effect of school building conditions on the students' academic achievement.

\section{Research Questions}

Four research questions were formulated to guide this study as follows:

- What is the extent of differences in the mean rating of secondary school buildings conditions in Adamawa State?

- To what extent do differences in school building conditions have effect on the mean academic achievement of secondary school students in Adamawa State?

- What is the extent of difference in the mean academic achievement of secondary school students in Adamawa State as a result of differences in their school locations (rural, semi-urban and urban areas)?

- What is the extent of the interactive effect of differences in school building conditions and school location(urban, semi-urban and rural) on the mean academic achievement of secondary school students in Adamawa State?

\section{Hypotheses}

To further investigate the level of significance of any effects of school building conditions and location on the academic achievement of secondary school students, five null hypotheses were formulated to strengthen the outcome of this research as follows:

- There is no significant difference in the mean rating of school building conditions among the secondary schools in Adamawa State.

- There is no significant effect of difference in school building conditions on the mean academic achievement of secondary school students in Adamawa State.

- There is no significant difference in mean achievement of secondary school students in standard school building conditions and those schooling under substandard school building conditions in Adamawa State.

- There is no significant difference in the mean academic achievement of secondary school students as a result differences in their school's locations within the urban, semi-urban and rural areas of Adamawa State.

- There is no significant no significant interactive effect of school building conditions and school locations on the mean academic achievement of secondary school students in Adamawa State.

\section{Methodology}

The study was conducted in two phases adopting a field-based survey design for the investigation. Three sampling techniques (stratified, purposive and simple random sampling techniques) were adopted to arrive at the study sample. The study adopted the three existing educational zones, namely, Adamawa North, Adamawa Central and Adamawa South for a smooth management of the population. In each zone, the local government areas were further stratified into urban centers (represented by the local government headquarters), semi-urban (represented by local government areas closest in educational development to the headquarters) and the rural areas (represented by one of the least educationally advanced local governments).from where representative schools were sampled. In all 27 study schools were statistically selected from the entire Adamawa state as shown in Table 1.

\begin{tabular}{|c|c|c|c|c|}
\hline \multirow{2}{*}{ Zone } & \multicolumn{3}{|c|}{ Local Government Location } & \multirow{2}{*}{ Total } \\
\cline { 2 - 4 } & Urban-based & Semi-urban-based & Rural Based & \\
\hline ZONE A & 3 & 3 & 3 & 9 \\
\hline ZONE B & 3 & 3 & 3 & 9 \\
\hline ZONE C & 3 & 3 & 3 & 9 \\
\hline TOTALS & 9 & 9 & 9 & 27 \\
\hline
\end{tabular}

Table 1: Distribution of the Study-Schools for Phase I of the Study

\subsection{Investigation Procedure}

The first phase of the study involved an inventory survey on the school building conditions from the 27 schools to enable the researcher to classify the buildings into standard and sub-standard building conditions. The researcher developed a structured checklist-type questionnaire, which was administered on the school administrators to rate their school building conditions. The criteria for rating the school buildings as developed by the researcher was guided by the combined indices from Cash's(1993) and Earthman (2004) study models. This gave a 10-point criterion for the classification of the building conditions for this study. These 10-point criteria include:

- Degree of Human Comfort (i.e., temperatures within the human comfort range);

- Condition of Indoor Air Quality (i.e., appropriate ventilation systems including fans and/ or Air Conditioners);

- Lighting Conditions - Natural and Public power lighting;

- Acoustical Control Conditions - Doors and windows with functional shutters and room ceiling;

- Adequate Laboratory/ Classroom carriage capacity;

- Most of the school buildings have been rehabilitated/ refurbished by ASUBEB

- More than half of the buildings are in bad shape/ out of use/ have defects;

- The average age of buildings is the school is above 25 years; 
- Deferred/ Frequency of Maintenance of the Buildings;

- Funding Priorities and Administrative Decisions;

Based on the analysis of the data collected from this rating, any school from a local government area with a mean score of 6.00 points and above for their buildings conditions were considered as standard, while any one that scored 5.90 points and below was selected as sub-standard for this study. From this rating, one school with the highest ranking was selected to represent standard school building group, while the school with the least score represented the sub-standard school buildings from each of the local government areas. A total of 6 schools were so selected from each zone, (see Table 2).

At the second phase of the study, the students' mean achievement scores in their national examination (NECO) in six commonly registered subjects at SSS III level (i.e. English language, Mathematics, Physics, Chemistry, Biology and Economics) were collated from the eighteen study-schools. The students' performance on the NECO and WAEC's 9-point grading system were converted to nominal raw scores using the mean of each range as the actual score (see Table 3 as a guide on the conversion).

\begin{tabular}{|c|c|c|c|c|c|}
\hline Zone & Local Govt. & \multicolumn{2}{|c|}{ School Building Condition } & \multicolumn{2}{|c|}{ Total } \\
\cline { 3 - 6 } & Area & Standard & Substandard & LGA & Zone \\
\hline Adamawa North & Mubi & 1 & 1 & 2 & 6 \\
& Michika & 1 & 1 & 2 & \\
\cline { 2 - 5 } & Maiha & 1 & 1 & 2 & \\
\hline \multirow{2}{*}{ Adamawa } & Yola North & 1 & 1 & 2 & 6 \\
\cline { 2 - 5 } & Numan & 1 & 1 & 2 & \\
\cline { 2 - 5 } & Guyuk & 1 & 1 & 2 & \multirow{2}{*}{6} \\
\hline Adamawa South & Ganye & 1 & 1 & 2 & \\
\cline { 2 - 5 } & Jada & 1 & 1 & 2 & \\
\cline { 2 - 5 } & Toungo & 1 & 9 & \multicolumn{2}{|c|}{18} \\
\hline & TOTAL & 9 & 1 & 1 & \\
\hline
\end{tabular}

Table 2: Distribution of the Study-Schools for Phase I of the Study

Thirty per cent of all the students that registered all the identified six subjects at the NECO and WEAC examinations for 2012/ 2013 and the 2013/ 2014 session were randomly selected for the investigation and this resulted to a sample size of 2430 students.

\begin{tabular}{|c|c|c|c|c|}
\hline S/ N0 & $\begin{array}{c}\text { NECO Grade } \\
\text { Point }\end{array}$ & $\begin{array}{c}\text { Nominal Score } \\
\text { Range (\%) }\end{array}$ & Mean of Range & Grade \\
\hline $\mathbf{1}$ & 9 & Below 30 & 15 & F- Fail(F9) \\
\hline $\mathbf{2}$ & 8 & $30-34$ & 32 & P - Pass(P8) \\
\hline $\mathbf{3}$ & 7 & $35-39$ & 37 & P - Pass(D7) \\
\hline $\mathbf{4}$ & 6 & $40-44$ & 42 & E - Credit(C6) \\
\hline $\mathbf{5}$ & 5 & $45-49$ & 47 & D - Credit(C5) \\
\hline $\mathbf{6}$ & 4 & $50-59$ & 54.5 & C- Credit(C4) \\
\hline $\mathbf{7}$ & 3 & $60-69$ & 64.5 & B - Credit(B2) \\
\hline $\mathbf{8}$ & 2 & $70-79$ & 74.5 & B $^{+}$- Distinction(B1) \\
\hline $\mathbf{9}$ & 1 & $80-100$ & 90 & A - Excellent(A1) \\
\hline
\end{tabular}

Table 3: Conversion Model from Grade Point to Raw Scores in This Study

\section{Data Presentation and Analysis}

The two different sets of data collected for this study are presented and analyzed under the different related research questions and the relevant hypotheses. A discussion of the findings follows thereafter.

\subsection{Research Question I}

What is the extent of differences in the mean rating of secondary school buildings conditions in Adamawa State? A summary of the data analysis on the secondary schools building conditions in Adamawa state in response to this research question is presented in Table 4. The data returned a weighted mean of 6.04 for the 27 buildings involved in this study (see the bottom row of Table 4). This data shows a measurable difference in the secondary schools building conditions across the entire state. 


\begin{tabular}{|c|c|c|c|c|c|}
\hline \multirow{2}{*}{$\begin{array}{c}\text { Education } \\
\text { Zone }\end{array}$} & \multirow{2}{*}{$\begin{array}{c}\text { Local Govt. } \\
\text { Area }\end{array}$} & \multicolumn{4}{|c|}{ School Building Conditions } \\
\hline & & $\begin{array}{c}\text { Standard School } \\
\text { Building Scores }\end{array}$ & $\begin{array}{l}\text { Sub-Standard School } \\
\text { Building Scores }\end{array}$ & $\begin{array}{l}\text { LGA Mean } \\
\text { Rating }\end{array}$ & $\begin{array}{l}\text { Zonal Mean } \\
\text { Rating }\end{array}$ \\
\hline \multirow{3}{*}{$\begin{array}{c}\text { Adamawa } \\
\text { Central }\end{array}$} & Yola North & 7.96 & 5.62 & 6.79 & \multirow[t]{3}{*}{6.29} \\
\hline & Numan & 7.53 & 5.15 & 6.34 & \\
\hline & Fufore & 6.91 & 4.57 & 5.74 & \\
\hline \multirow{3}{*}{$\begin{array}{l}\text { Adamawa } \\
\text { North }\end{array}$} & Mubi & 7.43 & 5.16 & 6.30 & \multirow[t]{3}{*}{6.12} \\
\hline & Michika & 7.61 & 4.87 & 6.24 & \\
\hline & Maiha & 6.85 & 4.81 & 5.83 & \\
\hline \multirow{3}{*}{$\begin{array}{l}\text { Adamawa } \\
\text { South }\end{array}$} & Ganye & 6.73 & 4.92 & 5.83 & \multirow[t]{3}{*}{5.72} \\
\hline & Jada & 6.70 & 4.80 & 5.75 & \\
\hline & Toungo & 6.65 & 4.49 & 5.57 & \\
\hline \multicolumn{2}{|c|}{ Weighted Mean } & 7.15 & 4.93 & 6.04 & \\
\hline
\end{tabular}

Table 4: Distribution of Adamawa Secondary Schools by Building Conditions

The information in this Table 4 shows that there are differences in the condition of secondary schools' buildings in Adamawa state within and between the local government areas and between different the sub-groups of urban, semiurban and rural areas. These summary data so far analyzed allowed the researcher to safely conclude that there are measurable differences in the conditions of secondary schools' buildings in Adamawa state.

\subsection{Research Question 2}

To what extent do differences in secondary school building conditions have effect on the mean academic achievement of secondary school students in Adamawa State?

A summary of the data analysis on the students' performances from their NECO and WAEC examination results for the 2012/ 2013 and 2013/ 2014 academic sessions (used as the standard measure of the students' academic achievement for this research) is presented in Table 5. The data in this table shows that the overall students' achievement returned a weighted mean of 48.21 for students under standard building conditions, irrespective of their school location subgroupings, while those under sub-standard buildings returned a weighted mean of 44.28 .

\begin{tabular}{|c|c|c|c|c|c|c|c|}
\hline \multirow[t]{3}{*}{ Zone } & \multirow[t]{3}{*}{ LGA } & \multicolumn{6}{|c|}{ School Records Under Different School Building Conditions } \\
\hline & & \multicolumn{3}{|c|}{ Standard Building Conditions } & \multicolumn{3}{|c|}{ Substandard Building Condition } \\
\hline & & Sample Size & $\begin{array}{l}\text { Sch. Mean } \\
\text { Score }\end{array}$ & $\begin{array}{c}\text { Zonal Mean } \\
\text { Score }\end{array}$ & $\begin{array}{l}\text { Sample } \\
\text { Size }\end{array}$ & $\begin{array}{l}\text { Sch. Mean } \\
\text { Score }\end{array}$ & $\begin{array}{l}\text { Zonal Mean } \\
\text { Score }\end{array}$ \\
\hline \multirow{3}{*}{$\begin{array}{c}\text { Adamawa } \\
\text { Central }\end{array}$} & Yola North & 80 & 53.55 & \multirow[t]{3}{*}{50.24} & 75 & 48.00 & \multirow[t]{3}{*}{44.22} \\
\hline & Numan & 61 & 49.67 & & 52 & 42.67 & \\
\hline & Fufore & 48 & 47.50 & & 43 & 42.00 & \\
\hline \multirow{3}{*}{$\begin{array}{l}\text { Adamawa } \\
\text { North }\end{array}$} & Michika & 56 & 49.67 & \multirow[t]{3}{*}{48.17} & 48 & 44.00 & \multirow[t]{3}{*}{42.06} \\
\hline & Mubi & 78 & 51.33 & & 68 & 45.17 & \\
\hline & Maiha & 28 & 43.50 & & 26 & 37.00 & \\
\hline \multirow{3}{*}{$\begin{array}{l}\text { Adamawa } \\
\text { South }\end{array}$} & Ganye & 45 & 47.67 & \multirow[t]{3}{*}{45.33} & 29 & 39.83 & \multirow[t]{3}{*}{39.88} \\
\hline & Jada & 38 & 44.50 & & 33 & 41.97 & \\
\hline & Toungo & 32 & 43.83 & & 29 & 37.83 & \\
\hline \multicolumn{2}{|c|}{ Total/ Group Means } & 358 & \multicolumn{2}{|c|}{47.91} & 403 & \multicolumn{2}{|c|}{42.05} \\
\hline
\end{tabular}

Table 5: Mean Academic Achievement of Students under Different School Building

Conditions and in Different Locations

This result shows that there is a measure of differences in the academic achievement of the students as a result of differences in their school building conditions with those schooling under standard school building conditions(48.21) performing relatively better than those schooling under sub-standard building conditions(44.28). Based on the analysis of the data in this Table 5, it is safe to conclude that there exist some measurable differences in secondary school students academic achievement as a result of differences in their school building conditions.

\subsection{Research Question 3}

What is the extent of differences in the mean academic achievement of secondary school students in Adamawa State as a result of differences in their school locations (rural, semi-urban and urban areas)?

A summary of the data analysis to investigate this research question is presented in Table 6 . The information from this Table 6 shows that there is a noticeable difference in the academic achievement of students as a result of differences in their school locations. The data presented in row 5 of Table 6 shows that the mean differences in students' academic achievement is skewed in favour of students schooling in the urban schools followed closely by those from semi-urban and lastly the rural schools. However, a slightly different trend occurred in Adamawa South schools, 


\begin{tabular}{|c|c|c|c|c|c|}
\hline \multirow{2}{*}{ Zone } & $\begin{array}{c}\text { Building } \\
\text { Conditions }\end{array}$ & \multicolumn{3}{|c|}{ School Locations } & $\begin{array}{c}\text { Zonal } \\
\text { Mean } \\
\text { Scores }\end{array}$ \\
\cline { 3 - 5 } & & Urban Schools & $\begin{array}{c}\text { Semi-Urban } \\
\text { Schools }\end{array}$ & $\begin{array}{c}\text { Rural } \\
\text { Schools }\end{array}$ & \\
\hline \multirow{2}{*}{$\begin{array}{c}\text { Adamawa } \\
\text { Central }\end{array}$} & $\begin{array}{c}\text { Standard } \\
\text { Buildings }\end{array}$ & 53.55 & 49.67 & 47.50 & 50.24 \\
\cline { 2 - 5 } & $\begin{array}{c}\text { Sub-Standard } \\
\text { Buildings }\end{array}$ & 48.0 & 42.67 & 42.00 & 44.22 \\
\hline \multirow{2}{*}{$\begin{array}{c}\text { Adamawa } \\
\text { North }\end{array}$} & $\begin{array}{c}\text { Standard } \\
\text { Buildings }\end{array}$ & 51.33 & 49.67 & 43.50 & 48.17 \\
\cline { 2 - 5 } & $\begin{array}{c}\text { Sub-Standard } \\
\text { Buildings }\end{array}$ & 45.17 & 44.00 & 37.00 & 42.06 \\
\hline \multirow{2}{*}{$\begin{array}{c}\text { Adamawa } \\
\text { South }\end{array}$} & $\begin{array}{c}\text { Standard } \\
\text { Buildings }\end{array}$ & 47.67 & 44.50 & 43.83 & 45.33 \\
\cline { 2 - 5 } & $\begin{array}{c}\text { Sub-Standard } \\
\text { Buildings }\end{array}$ & 39.83 & 41.93 & 37.83 & 39.86 \\
\hline & Group Mean & 47.59 & 45.41 & 42.94 & 44.98 \\
\hline
\end{tabular}

Table 6: Mean of Academic Achievement of Students under Different School Locations/ Building Conditions

Where students from the semi-urban schools (41.93\%) out-performed the urban(39.83\%) and rural(37.83\%) school students. The effect of school location can also be noticed when the data in column 6/ row 3(44.22\%) group mean for Adamawa Central students is compared with the data in column 6/ row 6 (45.33\%).

Based on the analysis so far it is only fair to conclude that the location the schools play a major role in the students' achievement at the secondary in school level. This issue is further handled under research question 4.

\subsection{Research Question 4}

What is the extent of the interactive effect of differences in school building conditions and school locations(urban, semi-urban and rural) on the academic achievement of secondary school students in Adamawa State?

The entire data collected for this study was split into two according to the interaction variables of building conditions and school location in response to this Research Question 4. The summary of the data analysis is presented in Tables 7 and 8 . The data under Table 7 show that the students schooling under standard building condition out-performed those under sub- standard building conditions with a clear difference of 5.84\%.

\begin{tabular}{|c|c|c|c|}
\hline \multirow{2}{*}{ S/ N0 } & \multicolumn{2}{|c|}{ Condition of the School Building } & \multirow{2}{*}{ Remarks } \\
\cline { 2 - 3 } & Standard Buildings & Sub-Standard Buildings & \\
\hline 1 & 53.35 & 48.00 & Yola North \\
\hline 2 & 49.67 & 42.67 & Numan \\
\hline 3 & 47.50 & 42.00 & Fufore \\
\hline 4 & 51.33 & 45.17 & Mubi \\
\hline 5 & 49.67 & 44.00 & Michika \\
\hline 6 & 43.50 & 37.00 & Maiha \\
\hline 7 & 47.67 & 39.83 & Genye \\
\hline 8 & 44.50 & 41.93 & Jada \\
\hline 9 & 43.83 & 37.83 & Toungo \\
\hline GROUP MEAN & 47.89 & 42.05 & \\
\hline
\end{tabular}

Table 7: Mean of Academic Achievement of Students under Different School Building Conditions

In other words, while students under standard school building conditions fall within the high margin of NECO/ WAEC credit levels, those under sub-standard school buildings fall below the credit class.

The result of the group means shows that there are differences in the students' academic achievement based on their school location with urban and rural schools showing the highest difference of $4.65 \%$. The differences between the urban and semi-urban schools, and between the semi-urban and rural schools appear to be marginal at 2.18 and 2.47 per cent respectively. 


\begin{tabular}{|c|c|c|c|c|}
\hline \multirow{2}{*}{ S/ N0 } & \multicolumn{3}{|c|}{ School Locations } & \multirow{2}{*}{ Remarks } \\
\cline { 2 - 4 } & Urban Schools & $\begin{array}{c}\text { Semi-Urban } \\
\text { Schools }\end{array}$ & Rural Schools & \multirow{2}{*}{ Adamawa Central } \\
\hline 1 & 53.55 & 49.67 & 47.50 & \multirow{2}{*}{ Adamawa North } \\
\hline 2 & 48.00 & 42.67 & 42.00 & \multirow{2}{*}{ Adamawa South } \\
\hline 3 & 51.33 & 49.67 & 43.50 & \\
\hline 5 & 45.17 & 44.00 & 43.00 & \\
\hline 6 & 47.67 & 44.50 & 37.83 & \\
\hline Group Mean & 39.83 & 41.93 & 42.94 & \\
\hline
\end{tabular}

Table 8: Mean of Academic Achievement of Students under Different School Locations

It is therefore safe, based on the information presented in Tables 7 and 8 , to conclude that although there are some noticeable differences in the students' academic achievement as a result of differences in their school locations, the differences are less except between the urban and rural schools $(2.18 \%, 2.47 \%$ \& $4.65 \%)$, when compared to the differences in their achievements based on school building conditions which is $5.84 \%$.

\section{Testing of the Hypotheses}

The student $t$-test statistics was adopted to test the different hypotheses as presented here:

\subsection{Hypothesis 1}

There is no significant difference in the secondary school building conditions in Adamawa state, Nigeria.

The data collected under Research Question 1 and presented in Table 4 on the condition of the 18 school buildings was subjected to a t-test analysis to affirm or reject Hypothesis 1. The summary statistics of the t-test analysis as presented in Table 9 returned a t-value of 21.147( $\mathrm{df}=17)$ at 0.000 level of significance. This result confirms that there is a significant difference in the conditions of school buildings in Adamawa state. The null hypothesis is therefore rejected. Based on the result of this analysis, the researcher safely concludes that there are significant differences exist in the condition of secondary school buildings within and between the different educational zones of Adamawa state. These differences, as shown by the data in Table 4, exist within and across the educational zones

\begin{tabular}{|c|c|c|c|c|c|c|c|}
\hline & tcal & tcrit & df & \multirow{2}{*}{$\begin{array}{c}\text { Sig. } \\
\text { (2-tailed) }\end{array}$} & $\begin{array}{c}\text { Mean } \\
\text { Difference }\end{array}$ & $\begin{array}{c}\text { 95\% Confidence Interval } \\
\text { of the Difference }\end{array}$ \\
\cline { 1 - 4 } & & & & & & Lower & Upper \\
\hline School Building Condition & 21.147 & 1.740 & 17 & .000 & 6.04222 & 5.4394 & 6.6450 \\
\hline
\end{tabular}

. Table 9: Summary Statistics of the T-Test Analysis of the School Building Conditions

\subsection{Hypothesis 2}

There is no significant effect of difference in school building conditions on the mean academic achievement of secondary school students in the in Adamawa State.

The t-test statistics was used to analyze the data collected under Research Question 2 in order to accept or reject this hypothesis. The summary of the t-test analysis as presented in Table 10 shows that the test returned a $t$-value of 46.046( $\mathrm{df}=17)$ at 0.000 level of significance. The null hypothesis is therefore rejected, and the alternate hypothesis upheld.

This result has not only supported the findings under Research Question 2 but has gone further to indicate clearly that the earlier finding of differences in the students' academic achievement as affected by their schools' building conditions are not only real but significant. The simple conclusion here is that secondary school students' academic achievement is significantly affected by the condition of their school buildings.

\begin{tabular}{|c|c|c|c|c|c|c|c|c|c|c|}
\hline & \multicolumn{5}{|c|}{ Paired Differences } & & & \multirow[t]{3}{*}{ Df } & \multirow{3}{*}{$\begin{array}{l}\text { Sig. } \\
\text { (2- } \\
\text { tailed) }\end{array}$} \\
\hline & & \multirow[t]{2}{*}{ Mean } & \multirow[t]{2}{*}{$\begin{array}{c}\text { Std. } \\
\text { Deviation }\end{array}$} & \multirow[t]{2}{*}{$\begin{array}{l}\text { Std. } \\
\text { Error } \\
\text { Mean }\end{array}$} & \multicolumn{2}{|c|}{$\begin{array}{l}\text { 95\% Confidence } \\
\text { Interval of the } \\
\text { Difference }\end{array}$} & & & & \\
\hline & & & & & Lower & Upper & $t_{\text {cal }}$ & $t_{\text {crit. }}$ & & \\
\hline Pair 1 & $\begin{array}{c}\text { Total } \\
\text { Student's } \\
\text { Mean Score } \\
\text { Total } \\
\text { Building } \\
\text { Condition } \\
\text { Score }\end{array}$ & 38.94056 & 3.58798 & .84569 & 37.15630 & 40.72481 & 46.046 & 1.740 & 17 & .000 \\
\hline
\end{tabular}

Table 10: Summary of the T-Test Analysis of the Paired Mean Scores for the

Building Conditions and Students Academic Achievement in Adamawa State 


\subsection{Hypothesis 3}

There is no significant difference in the academic achievement of secondary school students in standard school building conditions and those schooling under substandard school building conditions in Adamawa State.

The analysis under Hypothesis 2 was stretched a little further to determine the extent of these mean differences between the already determined standard school building conditions and those schooling under substandard school building conditions. The data for Research Question 2 as presented in Table 7 was used to test this hypothesis. The summary result of the t-test analysis is presented in Table 11.

\begin{tabular}{|c|c|c|c|c|c|c|c|c|c|c|}
\hline & \multicolumn{5}{|c|}{ Paired Differences } & & & \multirow[t]{3}{*}{ df } & \multirow{3}{*}{$\begin{array}{l}\text { Sig. (2- } \\
\text { tailed) }\end{array}$} \\
\hline & & \multirow[t]{2}{*}{ Mean } & \multirow[t]{2}{*}{$\begin{array}{c}\text { Std. } \\
\text { Deviation }\end{array}$} & \multirow[t]{2}{*}{$\begin{array}{l}\text { Std. } \\
\text { Error } \\
\text { Mean }\end{array}$} & \multicolumn{2}{|c|}{$\begin{array}{l}\text { 95\% Confidence } \\
\text { Interval of the } \\
\text { Difference }\end{array}$} & & & & \\
\hline & & & & & Lower & Upper & t-cal & t-critical & & \\
\hline $\begin{array}{c}\text { Pair } \\
1\end{array}$ & $\begin{array}{c}\text { Students } \\
\text { Mean Score } \\
\text { - Standard } \\
\text { Build. - } \\
\text { Students } \\
\text { Mean Score } \\
\text { - Sub- } \\
\text { standard } \\
\text { Build }\end{array}$ & 5.86111 & 1.46159 & .48720 & 4.73764 & 6.98459 & 12.030 & 1.860 & 8 & .000 \\
\hline
\end{tabular}

Table 11: Summary of Paired Samples T-Test of the of Students Performance under Standard and

Sub-Standard School Building Conditions in Adamawa State

A summary of the information in this Table 11 shows clearly that the calculated t-value at $12.030(\mathrm{df}=8)$ at 0.000 level of significance is far greater than the t-critical of 1.860. The null hypothesis is once again rejected in favour of the alternate hypothesis. From the outcome of this analysis it is safe to also conclude that there is significant difference in the mean academic achievement of secondary school students based on differences in their school building conditions in Adamawa state.

\subsection{Hypothesis 4}

There is no significant difference in the mean academic achievement of secondary school students as a result of their school's locations within the urban, semi-urban and rural areas of Adamawa State.

As noted earlier this research introduced one moderator variable of school location in order to clarify possible doubts on the effects of school building conditions on students' mean academic achievement. To do this, the study schools were stratified according to their location - urban, semi-urban and rural area - as earlier stated under the introduction of this research. The data on the mean students' achievement under this grouping has already been displayed in Table 9. A ttest analysis on this data was conducted and the summary is presented in Table 12. The data in this Table 12 show that the computed t-values of the three school location groupings are far greater than their t-critical values (see column $2 \& 3$, Table 12). The simple interpretation of this data is that the null hypothesis cannot stand. The alternate hypothesis that there are significant differences in secondary school students' academic achievement under different school building conditions, as influenced by their school locations is upheld.

Based on the result of all these analyses, the researcher safely concludes that there are significant differences in the academic achievement of secondary school students in Adamawa state as a result of differences in their school building conditions and school locations.

\begin{tabular}{|c|c|c|c|c|c|c|c|}
\hline & \multicolumn{7}{|c|}{ Test Value $=0$} \\
\hline & \multicolumn{2}{|c|}{$\mathrm{t}$} & \multirow[t]{2}{*}{$\mathrm{df}$} & \multirow[t]{2}{*}{$\begin{array}{c}\text { Sig. } \\
\text { (2-tailed) }\end{array}$} & \multirow[t]{2}{*}{$\begin{array}{c}\text { Mean } \\
\text { Difference }\end{array}$} & \multicolumn{2}{|c|}{$\begin{array}{c}\text { 95\% Confidence Interval of } \\
\text { the Difference }\end{array}$} \\
\hline & $\mathrm{cal}$ & critical & & & & Lower & Upper \\
\hline $\begin{array}{l}\text { Students' Mean Score } \\
\text { in Urban Schools }\end{array}$ & 24.228 & 2.015 & 5 & .000 & 47.59167 & 42.5422 & 52.6411 \\
\hline $\begin{array}{l}\text { Students' Mean Score } \\
\text { in Semi-urban Schools }\end{array}$ & 32.453 & 2.015 & 5 & .000 & 45.40667 & 41.8100 & 49.0033 \\
\hline $\begin{array}{l}\text { Students' Mean Score } \\
\text { in Rural Schools }\end{array}$ & 25.976 & 2.015 & 5 & .000 & 41.94333 & 37.7926 & 46.0941 \\
\hline
\end{tabular}

Table 12: Summary T-Test Analysis of Students Academic Achievement Based on Their School Locations

\subsection{Hypothesis 5}

There is no significant no significant interactive effect of school building conditions and school locations on the mean academic achievement of secondary school students in the in Adamawa State. 
This fifth hypothesis was generated to determine whether the combined effects that school building conditions and their locations have on the secondary school students' achievement were of any significance. The entire data collected on the students' academic achievement, those on their school buildings conditions and their school's locations were pulled together and analyzed. Once again, the t-test analysis returned computed t-values far greater than the critical t-values. The summary of the analysis is presented on Table 13. This result further illustrates the effect of school building conditions on students' academic achievement as combined with that of differences in their school locations. The variations in the calculated t-values (students achievement $=42.072$; building conditions $=21.147 \&$ school locations $=10.100$ ) as against the same t-critical (1.740) suggests that their variability is not the same.

\begin{tabular}{|c|c|c|c|c|c|c|c|}
\hline \multirow{2}{*}{} & \multicolumn{9}{|c|}{ Test Value = 0 } \\
\cline { 2 - 7 } & \multicolumn{2}{|c|}{$\mathrm{T}$} & $\mathrm{df}$ & $\begin{array}{c}\text { Sig. } \\
(2 \text {-tailed })\end{array}$ & $\begin{array}{c}\text { Mean } \\
\text { Difference }\end{array}$ & $\begin{array}{c}\text { 95\% Confidence Interval of } \\
\text { the Difference }\end{array}$ \\
\cline { 7 - 9 } & cal. & critical & & & & Lower & Upper \\
\hline Total Student's Mean Score & 42.072 & 1.740 & 17 & .000 & 44.98278 & 42.7270 & 47.2386 \\
\hline $\begin{array}{c}\text { Total Building Condition } \\
\text { Score }\end{array}$ & 21.147 & 1.740 & 17 & .000 & 6.04222 & 5.4394 & 6.6450 \\
\hline Schools Locations & 10.100 & 1.740 & 17 & .000 & 2.00000 & 1.5822 & 2.4178 \\
\hline
\end{tabular}

Table 13: Summary of the T-Test Analysis of the Interactive Effect of School Building Conditions and

School Locations on the Students Academic Achievement Based on Their School Locations

To further identify which of the variables have greater effect than the other, a factor analysis of the data on the three variables - Students' Achievement, School Buildings Conditions and School Locations was conducted. A summary of the correlation matrix from the factor analysis is presented in Table 14. The information in this Table 14 clearly shows that the students' academic achievement is highly positively associated $(r=0.834)$ with their school building conditions, while their school locations showed a low negative correlation $(r=-0.479)$ with the students' academic achievement.

\begin{tabular}{|c|c|c|c|c|}
\hline & $\begin{array}{c}\text { Total Student's } \\
\text { Mean Score }\end{array}$ & $\begin{array}{c}\text { Total Building } \\
\text { Condition Score }\end{array}$ & $\begin{array}{c}\text { Schools } \\
\text { Locations }\end{array}$ \\
\hline Correlation & Total Student's Mean Score & 1.000 & .834 & -.479 \\
\hline & Total Building Condition Score & .834 & 1.000 & -.204 \\
\hline & Schools Locations & -.479 & -.204 & 1.000 \\
\hline Sig. (1-tailed) & Total Student's Mean Score & & .000 & .022 \\
\hline & Total Building Condition Score & .000 & & .208 \\
\hline & Schools Locations & .022 & .208 & \\
\hline
\end{tabular}

Table 14: Summary of the Correlation Matrix from Factor Analysis of the Three Variables in This Study

Based on the result of all these analyses, the researcher safely concludes that there are significant differences in the academic achievement of secondary school students in Adamawa state as a result of differences in their school building conditions, which is further stressed by the difference in the geographical location of their schools. The null hypothesis 5 is therefore rejected in favour of the alternative that there is a significant interactive effect of school building conditions and school locations on the academic achievement of secondary school students in Adamawa state.

\section{Discussion on the Findings}

The building assessment information from this study indicates that a large portion of Adamawa state secondary school buildings are more than 30 years old and have a number of structural and classroom defects. While the school administrators gave high composite ratings to their schools, their responses to specific school-based questions showed problems with roof leaks and human comfort and indoor air quality. It is also fair to mention that during the field survey, the researcher discovered that Adamawa State Universal Basic Education Board(ASUBEB) has been doing a wonderful job in the renovation/ rehabilitation of many secondary school buildings in the state, without which most of the schools, especially those within the rural settlements would have had little or nothing to write home about.

Specifically, this study has clearly revealed that there is a significant difference in school building conditions within and between the local governments in Adamawa state. Secondly the study discovered that in addition to the devastating effects of the Boko-haram insurgency, many secondary school building conditions in Adamawa state are below standard; This findings of this research has clearly demonstrated that in spite of the contradictory community statements about the location of schools, poor condition of the school buildings often creates feelings of inadequacy on the part of students and their teachers. This is especially true when the students represent economically disadvantaged/rural populations. This is because quite often low standard school buildings that are in poor conditions were more commonly found within the semi-urban and rural areas or squalor areas of the state. These poor quality facilities generally present environments which are inadequate to support current teaching methods and inhibit good teaching and learning and school's authorities within such localities usually do not have the financial resources to improve the conditions of these buildings. Another reality of the state discovered from this study is that a preponderance of economically disadvantaged and rural students live in areas where the school buildings are typically deficient. Clearly this creates a situation for an 
equity difference. The longer students attend school under such poor building conditions, the greater they are deficit in their academic achievements.

Presently in Nigeria and Adamawa in particular, issues related to school building conditions, the ability to provide good instruction, and student achievement has become particularly important in the light of the expectations of the federal government that "No child is denied schooling opportunity in Nigeria". This agenda requires that schools close the achievement gaps of students who come from socio-economically challenged families as well as those who are in certain areas designated as rural and semi-urban subgroups including the nomads. This notwithstanding, this study has identified that prevailing poor school building conditions may prove to be a significant barrier that will impede the efforts of school personnel as they attempt to close students' academic achievement gaps. There is therefore, a significant challenge for both rural and urban schools where building conditions often do not meet acceptable standards to meet-up the federal governments expectations of qualitative academic achievement of all Nigerian. This fear is predicated on the major finding of this study that students studying under standard building conditions have higher academic achievement than those under sub-standard school buildings and that there is a near perfect positive correlation $(r=0.834)$ between the achievement of students and their school building conditions. In specific terms, this study discovered that, while differences in the quality of secondary school building conditions contribute significantly to the differences in the academic achievement of the students in Adamawa state, these differences are further stressed by the location of the school in favour of urban-based schools against semi-urban- and rural-based secondary schools.

\section{Conclusion}

This study has taken the researcher quiet some time in data gathering and analysis and the subsequent write-up. This report, coming out at this time appears not only relevant but very timely as the Adamawa state government continues in her efforts at arresting the rot in education under its declaration of a "State of Emergency on Education" by the present (Alh. Umaru Bindo Jibrilla's) administration. The findings of this study are clearly based on verifiable real value data within Adamawa state secondary schools and is believed to be capable of guiding the government and other stake-holders in education, in taking concrete decisions/actions to improve the quality of education that will reflect on the quality of students' academic achievement in Adamawa state and Nigeria as a whole.

\section{References}

i. Brannon, W. (2000). A study of the relationship between school leadership and the condition of school buildings. Unpublished doctoral dissertation. Blacksburg, VA: Virginia Polytechnic Institute and State University.

ii. Cash, C. (1993). A study of the relationship between school building condition and student achievement and behavior. Unpublished doctoral dissertation. Blacksburg, VA: Virginia Polytechnic Institute and State University.

iii. Cheng, Y.C. (1994). Classroom environment and student affective performance: An effective profile. Journal of Experimental Education, 62(3), 221-239.

iv. Crook, J. (2006). The relationship between the percentage of students' passing the standards of learning examinations and the condition of the educational facilities in the high schools in the Commonwealth of Virginia. Unpublished doctoral dissertation. Blacksburg, VA: Virginia Polytechnic Institute and State University.

v. Daramola, D. S., Olutola, A. T. and Ogunjimi, M. O.(2017), Assessing the Impact of School Environment on Academic Performance of Senior Secondary Students in Economics: International Journal Of Educational Benchmark (Ijeb), University of Uyo, Vol. 8(2)

vi. $\quad$ Duke, D.L., Griesdorn, J., Gillespie, M., and Tuttle, J.B. (1998). Where our children

vii. learn matters: A report on the Virginia school facilities impact study. Charlottesville, VA: The Thomas Jefferson Center for Educational Design.

viii. Earthman, G.I., Cash, C.S., and Van Berkum, D. (1995). A statewide study of student achievement and behavior and school building condition. Council of Educational Facility Planners, International (CEFPI) Annual Meeting, Dallas, TX. 104

ix. Earthman, G.I. (2002). School facility conditions and student academic achievement. UCLA's Institute for Democracy, Education, \& Access. Los Angeles, California.

x. Earthman, G.I. (2004). Executive Summary: Prioritization of 31 criteria for school building adequacy. American Civil Liberties Union Foundation of Maryland. Baltimore, MD.

xi. Gabler, J. (1987). School buildings need to become more inviting. The School Administrator, 44(6), 6.

xii. Hawkins, H.L. \& Lilley, H.E. (1998). Guide for school facility appraisal. Phoenix, AZ: The Council of Educational facility Planners International.

xiii. Hines, E.W. (1996). Building condition and student achievement and behavior. Unpublished doctoral dissertation, Virginia Polytechnic Institute and State University.

xiv. Ibrahim , W. Y., Umar, H.A. and Igbaji Clement(2017), Impact Of School Facilities On; Students' Academic Achievement; International Journal of Advanced Research(IJAR), Vol. 5(12), pp 878-889.

xv. Joseph Sunday Owoeye, J. S. and Yara, P.O., (2011); School Facilities and Academic Achievement of Secondary School Agricultural Science in Ekiti State, Nigeria: Asian Journal of Social Science Vol. 7, No. 7; July 2011

xvi. Torupere, K., (2016), The Influence of School Physical Environment on Secondary School Students' Academic Performance in Bayelsa State: Asian Journal of Educational Research, Vol. 4 